\title{
The Use of a Robust Capture-Recapture Design in Small Mammal Population Studies: A Field Example with Microtus pennsylvanicus
}

\author{
James D. NICHOLS, Kenneth H. POLLOCK ${ }^{1}$ \& James E. HINES
}

Nichols J. D., Pollock K. H. \& Hines J. E., 1984: The use of a robust capture-recapture design in small mammal population studies: a field example with Microtus pennsylvanicus. Acta theriol, 29, 30: 357-365 [With 5 Tables]

The robust design of Pollock (1982) was used to estimate parameters of a Maryland Microtus pennsylvanicus population. Closed model tests provided strong evidence of heterogeneity of capture probability, and model $M_{h}$ (Otis et al., 1978) was selected as the most appropriate model for estimating population size. The Jolly-Seber model goodness-of-fit test indicated rejection of the model for this data set, and the $M h$ estimates of population size were all higher than the Jolly-Seber estimates. Both of these results are consistent with the evidence of heterogeneous capture probabilities. We thus used $M h$ estimates of population size, Jolly-Seber estimates of survival rate, and estimates of birth-immigration based on a combination of the population size and survival rate estimates. Advantages of the robust design estimates for certain inference procedures are discussed, and the design is recommended for future small mammal capture-recapture studies directed at estimation.

[U. S. Fish and Wildlife Service, Patuxent Wildlife Research Center, Laurel, Maryland, 20708, U.S.A.; ${ }^{1}$ Department of Statisties, Box 5457, North Carolina State University, Raleigh, North Carolina, 27650, U.S.A.]

\section{INTRODUCTION}

Jolly \& Dickson (1983) and Nichols \& Pollock (1983) discussed estimation methodology in small mammal capture-recapture studies and recommended the use of estimators based on probabilistic models rather than direct enumeration. Nichols \& Pollock (1983) suggested that the robust design of Pollock (1982) might be especially useful in small mammal studies. Briefly, this design involves $K$ "primary" (e.g., monthly) sampling periods and $l$ "secondary" (e.g., daily) sampling periods within each of the $K$ primary periods. Population size is estimated from capture histories within the secondary sampling periods using closed population models (see Otis et al., 1978), and survival rate is estimated from capture histories over the primary periods using open population models (e.g., Jolly, 1965, 1982; Seber, 1965; Pollock, 1981). This design thus exploits the robust nature of open model survival rate estimators (see Cormack, 1972; Carothers, 1973; Nichols et al., 1983) and the diversity of closed 
models that permit estimation of population size under various assumptions of unequal capture probabilities.

Recently, we tested the applicability of the robust design in a capturerecapture study of a Microtus pennsylvanicus population. Here we present results of that experiment in order to illustrate the robust design and demonstrate its utility in small mammal studies. We also discuss advantages of robust design estimators for use in certain inference procedures.

\section{METHODS}

A livetrapping grid was set out in November, 1980, by R. K. Rose in old field habitat at Patuxent Wildlife Research, Center, Laurel, MD. The grid contained a $10 \times 10$ matrix of trapping stations spaced at $7.6 \mathrm{~m}$ intervals. A single modified Fitch live trap (Rose, 1973) was placed at each station. Hay and dried grass were placed in the nest box sections of the traps and whole corn was used as bait.

Primary sampling periods for the robust design experiment occurred monthly from June, 1981, until December, 1981. Within each primary period, traps were set one evening, run the following morning, locked open during the day, and reset in the evening. This procedure was repeated for 5 consecutive days within each of the 6 monthly periods. A raccoon, Procyon lotor, (later captured) visited the grid and tipped over a substantial number of traps on the final 2 days of trapping for the second of the 6 monthly periods. Data from these 2 days were not used in the closed model analysis leaving only 3 trapping days in the second month.

At each capture animals were sexed and weighed and information on external reproductive characteristics obtained. Unmarked animals were ear-tagged with numbered fingerling tags, and tag numbers of marked animals were recorded.

Subadult and adult animals $(\geqslant 22 \mathrm{~g}$, Krebs et al., 1969) of both sexes were combined in our analysis. Jolly-Seber open model estimates of survival rate and population size were obtained using the bias-adjusted estimates recommended by Seber $(1973: 204)$. We report the conditional variance estimates that reflect only sampling variation or "error of estimation" (Jolly, $1965: 238$ ). Fit of the data to the Jolly-Seber model was assessed using a goodness-of-fit test recently proposed by Pollock, Hines \& Nichols (in prep.). Closed model estimates, goodness-of-fit statistics and model selection statistics were computed using the methodology and algorithm (CAPTURE) of Otis et al. (1978; also see White et al., 1978).

\section{RESULTS}

The Microtus population was high throughout the experiment. We captured 311 individual animals a total of 1978 times. Primary sampling period capture histories and secondary period histories are summarized in Tables 1 and 2 , respectively.

The closure test in program CAPTURE indicated rejection of the closure hypothesis for the first sampling period but not for any other 
Table 1

Capture history data over primary sampling periods summarized in Leslie Method B Table (Leslie 1952) format.

\begin{tabular}{|c|c|c|c|c|c|c|}
\hline \multirow{2}{*}{$\begin{array}{l}\text { Period last } \\
\text { captured (dates) }\end{array}$} & \multicolumn{6}{|c|}{ Period captured } \\
\hline & 1 & 2 & 3 & 4 & 5 & 6 \\
\hline $\begin{array}{ll}1 & (6 / 27-7 / 1) \\
2 & (8 / 1-8 / 5) \\
3 & (8 / 29-9 / 2) \\
4 & (10 / 3-10 / 7) \\
5 & (10 / 31-11 / 4) \\
6 & (12 / 4-12 / 8)\end{array}$ & - & 84 & $\begin{array}{r}5 \\
68 \\
-\end{array}$ & $\begin{array}{r}0 \\
7 \\
66 \\
-\end{array}$ & $\begin{array}{r}0 \\
0 \\
2 \\
59 \\
-\end{array}$ & $\begin{array}{r}0 \\
1 \\
0 \\
4 \\
84 \\
\end{array}$ \\
\hline $\begin{array}{l}\text { Marked animals caught } \\
\text { Unmarked animals caught } \\
\text { Total animals caught } \\
\text { Total animals released }\end{array}$ & $\begin{array}{r}0 \\
108 \\
108 \\
105\end{array}$ & $\begin{array}{r}84 \\
43 \\
127 \\
121\end{array}$ & $\begin{array}{r}73 \\
29 \\
102 \\
101\end{array}$ & $\begin{array}{r}73 \\
30 \\
103 \\
102\end{array}$ & $\begin{array}{r}61 \\
41 \\
102 \\
100\end{array}$ & $\begin{array}{r}89 \\
60 \\
149 \\
148\end{array}$ \\
\hline
\end{tabular}

Table 2

Capture frequency data for the secondary sampling periods within each primary period.

\begin{tabular}{|c|c|c|c|c|c|c|}
\hline \multirow{2}{*}{$\begin{array}{l}\text { Primary period } \\
\text { (month) }\end{array}$} & \multirow[b]{2}{*}{ Statistic a } & \multicolumn{5}{|c|}{ Secondary period (day) } \\
\hline & & 1 & 2 & 3 & 4 & 5 \\
\hline $\begin{array}{l}\mathrm{A} \\
\mathrm{F}\end{array}$ & $\begin{array}{l}\text { Animals caught } \\
\text { Frequency }\end{array}$ & $\begin{array}{l}63 \\
20\end{array}$ & $\begin{array}{l}72 \\
15\end{array}$ & $\begin{array}{l}74 \\
21\end{array}$ & $\begin{array}{l}65 \\
21\end{array}$ & $\begin{array}{l}63 \\
28\end{array}$ \\
\hline $\begin{array}{l}\text { A } \\
\text { F }\end{array}$ & $\begin{array}{l}\text { Animals caught } \\
\text { Frequency }\end{array}$ & $\begin{array}{l}66 \\
35\end{array}$ & $\begin{array}{l}81 \\
37\end{array}$ & $\begin{array}{l}82 \\
40\end{array}$ & $\begin{array}{l}-\mathrm{b} \\
\text { - }^{\mathrm{b}}\end{array}$ & - \\
\hline $\begin{array}{l}\mathrm{A} \\
\mathrm{F}\end{array}$ & $\begin{array}{l}\text { Animals caught } \\
\text { Frequency }\end{array}$ & $\begin{array}{l}53 \\
37\end{array}$ & $\begin{array}{l}54 \\
23\end{array}$ & $\begin{array}{l}46 \\
16\end{array}$ & $\begin{array}{l}47 \\
13\end{array}$ & $\begin{array}{l}43 \\
12\end{array}$ \\
\hline$\stackrel{A}{F}$ & $\begin{array}{l}\text { Animals caught } \\
\text { Frequency }\end{array}$ & $\begin{array}{l}60 \\
29\end{array}$ & $\begin{array}{l}62 \\
15\end{array}$ & $\begin{array}{l}61 \\
15\end{array}$ & $\begin{array}{l}52 \\
16\end{array}$ & $\begin{array}{l}68 \\
27\end{array}$ \\
\hline $\begin{array}{l}\mathrm{A} \\
\mathrm{F}\end{array}$ & $\begin{array}{l}\text { Animals caught } \\
\text { Frequency }\end{array}$ & $\begin{array}{l}60 \\
19\end{array}$ & $\begin{array}{l}67 \\
19\end{array}$ & $\begin{array}{l}65 \\
19\end{array}$ & $\begin{array}{l}56 \\
17\end{array}$ & $\begin{array}{l}64 \\
26\end{array}$ \\
\hline $\begin{array}{l}\text { A } \\
\text { F }\end{array}$ & $\begin{array}{l}\text { Animals caught } \\
\text { Frequency }\end{array}$ & $\begin{array}{l}87 \\
40\end{array}$ & $\begin{array}{l}89 \\
28\end{array}$ & $\begin{array}{l}79 \\
32\end{array}$ & $\begin{array}{l}85 \\
28\end{array}$ & $\begin{array}{l}64 \\
20\end{array}$ \\
\hline
\end{tabular}

a Animals caught denotes number of animals caught on each day of trapping. Frequency denotes the number of animals caught on 1 , $2,3,4$, and 5 occasions.

$b$ A raccoon tipped over traps on the final 2 days of the second primary period, and these data were omitted from the analysis.

periods (Table 3). This test can result in false rejection in certain: situations (Otis et al., 1978:66-67), and we decided to use the closed model estimates for all periods.

Program CAPTURE includes models which permit heterogeneity of 
capture probabilities (variation from individual to individual), behavioral response (different capture probabilities for marked and unmarked animals), and temporal variation (from 1 trapping occasion to the next), as well as all possible combinations of these sources of variation. CAPTURE also includes a discriminant function model selection procedure. This procedure chose the heterogeneity model, $M_{h}$, in all periods except month 2 . However, month 2 had only 3 trapping days, and we decided to use $M_{h}$ for this month also because the model selection procedure does not perform well with such a small number of sampling periods. The $M_{h}$ goodness-of-fit statistics generally supported the use of this model, and the $M_{0}$ vs. $M_{h}$ test (essentially a test for heterogeneity of capture probability) results provided strong evidence of heterogeneity for every month (Table 3).

Table 3

Test statistios for population closure and $M h$ goodness-of-fit based on data in Table 2.

\begin{tabular}{|c|c|c|c|c|c|c|c|c|}
\hline \multirow{2}{*}{$\begin{array}{l}\text { Primary period } \\
\text { (month) }\end{array}$} & \multicolumn{2}{|c|}{ Closure test } & \multicolumn{3}{|c|}{$\underline{M h}$ goodness-of-fit } & \multicolumn{3}{|c|}{ Mo vs. $M h^{a}$} \\
\hline & $z$ & $P$ & $x^{2}$ & df & $P$ & $x^{2}$ & df & $P$ \\
\hline 1 & -1.90 & 0.03 & 5.7 & 4 & 0.22 & 73.0 & 3 & 0.00 \\
\hline 2 & -1.16 & 0.12 & 6.7 & 2 & 0.04 & 8.1 & 1 & 0.00 \\
\hline 3 & 0.59 & 0.72 & 4.1 & 4 & 0.39 & 67.6 & 3 & 0.00 \\
\hline 4 & 0.65 & 0.74 & 7.3 & 4 & 0.12 & 120.8 & 3 & 0.00 \\
\hline 5 & -0.52 & 0.30 & 4.2 & 4 & 0.39 & 66.9 & 3 & 0.00 \\
\hline 6 & -1.13 & 0.13 & 12.9 & 4 & 0.01 & 62.8 & 3 & 0.00 \\
\hline
\end{tabular}

a $M_{0}$ vs. $M h$ essentially tests for heterogeneity of capture probabilities (Otis et al., $1978: 52-56$ ).

The goodness-of-fit test statistic for the Jolly-Seber model indicated strong rejection of the model for our data set $\left(\chi^{2}=30.9,5 \mathrm{df}, P<0.01\right)$. This test is sensitive to heterogeneity of capture probability when average capture probability is high (Pollock et al., in prep.), and test results are thus consistent with the evidence of heterogeneity provided by the closed models.

Population size estimates were computed using both the Jolly-Seber open model and the closed model, $M_{h}$ (Table 4). Jolly-Seber estimates can be computed for months $2-5$, while closed model estimates can be computed for each period, $1-6$. The $M_{h}$ estimates of average capture probability (this represents the probability that an animal will be caught on any particular day or secondary sampling period) ranged from 0.35 to 0.56 and produced fairly precise $\hat{N}_{t}$. The Jolly-Seber estimates of capture probability (this represents the probability that an animal will 
Table 4

Comparison of Microtus population size estimates using population model $M_{h}$ (robust procedure) and using the Jolly-Seber model. Standard errors are given in parentheses.

\begin{tabular}{ccccc}
\hline Primary & \multicolumn{2}{c}{$M h$} & Jolly-Seber Model \\
\hline 1 & 123 & $(5.2)$ & \multicolumn{2}{c}{${ }^{-}$} \\
2 & 144 & $(6.9)$ & 138 & $(4.3)$ \\
3 & 141 & $(10.0)$ & 118 & $(4.5)$ \\
4 & 140 & $(10.9)$ & 109 & $(3.1)$ \\
5 & 115 & $(4.7)$ & 111 & $(3.1)$ \\
6 & 189 & $(10.3)$ & & \\
\hline
\end{tabular}

a Trap losses in each month of $3,6,1,1,2,1$ were added to the $M_{h}$ estimates.

be captured at least once during a 5-day or primary sampling period) are very high (mean, $\bar{p}=0.91$ ) and the Jolly-Seber population size estimates, $\hat{N}_{i}$, are thus very precise (small standard errors). Jolly-Seber $\hat{N}_{i}$ are negatively biased in the presence of heterogeneity, but bias should be relatively small when capture probability is high (Carothers, 1973; Gilbert, 1973). Nevertheless, in every month for which a comparison is possible, the population estimate based on $M_{h}$ is higher than the JollySeber estimate (Table 4). Thus, despite the greater precision of the JollySeber estimates, we prefer the $M_{h}$ estimates which should exhibit lower bias. We also note that Jolly-Seber capture probabilities would be lower with the 2- or 3-day trapping periods characteristic of most small mammal studies. This would produce less precision and more bias in the Jolly-Seber $\widehat{N}_{i}$.

The Jolly-Seber survival rate estimator $\hat{\varphi}$, is robust to heterogeneity of capture probability (Carothers, 1973) and is not biased by permanent trap response (Nichols et al., 1983). We thus believe that our survival

Table 5

Estimated survival rates and numbers of new animals entering the population. Survival rates are estimated using the Jolly-Seber model, and numbers of new animals are estimated using both the robust procedure and the Jolly-Seber model. Standard errors are given in parentheses.

\begin{tabular}{|c|c|c|c|c|c|c|}
\hline \multirow{2}{*}{$\begin{array}{l}\text { Primary } \\
\text { period }\end{array}$} & \multirow{2}{*}{\multicolumn{2}{|c|}{$\begin{array}{l}\text { Survival rates } \\
\text { (Jolly-Seber) }\end{array}$}} & \multicolumn{4}{|c|}{ Numbers of new animals } \\
\hline & & & \multicolumn{2}{|c|}{ Robust } & \multicolumn{2}{|c|}{ Jolly-Seber } \\
\hline 1 & 0.88 & $(0.021)$ & 39 & ( 8.7$)$ & & - \\
\hline 2 & 0.66 & $(0.023)$ & 50 & (11.5) & 31 & (3.6) \\
\hline 3 & 0.69 & $(0.022)$ & 43 & (13.2) & 29 & (2.9) \\
\hline 4 & 0.63 & $(0.015)$ & 28 & $(8.5)$ & 43 & $(3.1)$ \\
\hline E & \multicolumn{2}{|c|}{ _ } & \multicolumn{2}{|c|}{$-^{20}(0.0)$} & \multicolumn{2}{|c|}{ - } \\
\hline
\end{tabular}


estimates should exhibit very little bias (Table 5). Because of our high capture probabilities, these estimates are very precise (Table 5).

Recruitment, $B_{t}$, or the number of individual's entering the population between times $i$ and $i+1$, and present at time $i+1$, is estimated as:

$$
\hat{B}_{i}=\hat{N}_{i+1} \hat{\varphi}_{i}\left(\hat{N}_{i}-n_{i}+R_{i}\right)
$$

where $n_{i}$ and $R i$ are the numbers of animals caught and released, respectively, at period $i$. Jolly-Seber $B_{t}$ are estimated by using JollySeber $\hat{N}_{i}$ in (1), while the robust design uses $N i$ from the closed models (eg., $M_{h}$ ). An estimate of $B_{1}$ is possible with the robust design but not with the Jolly-Seber model. For the 3 periods in which a comparison is possible, the robust design yields higher estimates of $B_{t}$ in 2 periods while the Jolly-Seber $\hat{B}_{1}$ is higher in 1 period (Table 5). Jolly-Seber $B i$ are more precise than the robust $\hat{B}_{i}$, but the latter should exhibit. less bias.

\section{DISCUSSION}

This example illustrates well the potential importance of the robust. design to small mammal capture-recapture studies. The design produced very precise estimates of survival' rate, population size and recruitment which would permit powerful tests of hypotheses dealing with small mammal population ecology. The closed model tests (Table 3) strongly indicated heterogeneity of capture probabilities, and model $M_{h}$ permits robust estimation of population size in this situation. Since heterogeneity is believed to be common among small mammals (see Smith et al., 1975) we believe the robust design will often be preferable to the Jolly-Seber methodology.

Lefebvre et al. (1982) used a trapping schedule which permitted estimation of Sigmodon hispidus population size using both closed and open models. They found strong evidence of heterogeneity of capture probability, as we did, and used $M_{h}$ as the most appropriate closed model in the majority of sampling periods. They did not find a consistent directional relationship between Jolly-Seber and closed model population estimates (i.e., the estimates were similar, but 1 was not always larger than the other). Perhaps heterogeneity was really not a problem during the several sampling periods in which they failed to detect it. They did not test the goodness-of-fit of the Jolly-Seber model, and they did not exploit the ability of their design to yield robust estimates of $\varphi i$ and $\mathrm{Bi}$.

Although the robust design was developed to permit robust parameter 
estimation, we note here that it also has advantages in certain inference procedures. A problem in many important small mammal studies during the last 2 decades involves the use of estimators having a non-negligible sampling correlation to draw inferences about underlying parameters. For example, a number of papers have addressed questions about the relationship between population size and other parameters such as survival rate. Such questions are typically addressed using estimates of population size and survival rate which have a built-in sampling correlation and which would thus tend to indicate a particular type of relationship even in the absence of a relationship between the true underlying parameters. Another common practice in small mammal population studies is to treat population size or rate of increase (ratio of 2 successive population sizes) as the dependent variable in a multiple regression analysis and quantities such as survival rate as independent variables. Naturally, when correlated estimates are used in such analyses they may produce misleading results. Enumeration estimates have been used in most analyses of this type, and a sampling correlation does exist between the population size and survival rate estimates. Although Jolly-Seber estimates have been recommended for future small mammal work (Nichols \& Pallock, 1983), we note that Jolly-Seber estimates of survival rate and population size also exhibit a sampling correlation. By using different types of data to estimate $\mathrm{Ni}$ and $\varphi \mathrm{i}$, the robust design yields independent estimates of these parameters which can be used to address questions about true functional relationships.

As noted by Pollock (1982), the major problem associated with the robust design is the large trapping effort required. Otis et al. (1978) recommend a minimum of 5 days of trapping for good performance of their closed population models, and this represents a substantial effort to be expended at each primary trapping period. However, many small mammal studies involve $2-3$ days trapping every 2 weeks. Redistribution of sampling to 5 days every month would represent similar effort and would produce the advantages of robust and precise estimation of population size, survival rate, and recruitment. We therefore recommend this design for future small mammal capture-recapture studies aimed at estimating demographic parameters.

Acknowledgements: We thank M. Erwin, M. Fuller, M. Haramis and M. Perry for reviewing the manuscript and $\mathbf{R}$. Wilcox for typing it.

\section{REFERENCES}

1. Carothers A. D., 1973: The effects of unequal catchability on Jolly-Seber estimates, Biometrics, 29: 79-100. 
2. Cormack R. M., 1972: The logic of capture-recapture estimates. Biometrics, 28: $337-343$.

3. Gilbert R. O., 1973: Approximations of the bias in the Jolly-Seber capturerecapture model. Biometrics, 29: 501-526.

4. Jolly G. M., 1965: Explicit estimates from capture-recapture data with both death and immigration-stochastic model. Biometrika, 52: 225-247.

5. Jolly G. M., 1982: Mark-recapture models with parameters constant in time. Biometrics, 37: 301-321.

6. Jolly G. M. \& Dickson J. M., 1983: The problem of unequal catchability in mark-recapture estimation of small mammal populations. Can. J. Zool., 61: 922-927.

7. Krebs C. J., Keller B. L. \& Tamarin R. H., 1969: Microtus population biology: demographic changes in fluctuating populations of $M$. ochrogaster and $M$. pennsylvanicus in southern Indiana. Ecology, 50: 587-607.

8. Lefebvre L. W., Otis D. L. \& Holler N. R., 1982: Comparison of open and closed models for cotton rat population estimates. J. Wildl. Manage, 46: $156-163$.

9. Leslie P. H., 1952: The estimation of population parameters by means of the capture-recapture method. II. The estimation of total numbers. Biometrika, 39: $363-388$.

10. Nichols J. D. \& Pollock K. H., 1983: Estimation methodology in contemporary small mammal capture-recapture studies. J. Mammal., 64: 253-260.

11. Nichols J. D., Hines J. E. \& Pollock K. H., 1984: Effects of permanent trap response in capture probability on Jolly-Seber capture-recapture model estimates. J. Wildl. Manage., 48: 289-294.

12. Otis D. L., Burnham K. P., White G. C. \& Anderson D. R., 1978: Statistical inference from capture data on closed animal populations. Wildl. Monogr., 62: $1-135$.

13. Pollock K. H., 1981: Capture-recapture models allowing for age-dependent survival and capture rates. Biometrics, 37: 521-529.

14. Pollock K. H., 1982: A capture-recapture sampling design robust to unequal catchability. J. Wildl. Manage., 46: 752-757.

15. Rose R. K., 1973: A small mammal live trap. Trans. Kans. Acad. Sci., 76: $14-17$.

16. Seber G. A. F., 1965: A note on the multiple recapture census. Biometrika, 52: 249-259.

17. Seber G. A. F., 1973: The estimation of animal abundance and related parameters. Griffin: 1-506. London.

18. Smith M. H., Gardner R. H., Gentry J. B. Kaufman D. W. \& O'Farrell M. H., 1975: Density estimation of small mammal populations. [In: "Small mammals: their productivity and population dynamics", F. B. Golley, K. Petrusewicz, and L, Ryszkowski, eds.]. Cambridge Univ. Press: 25-53. Cambridge.

19. White G. C., Burnham K. P., Otis D. L. \& Anderson D. R., 1978: User's manual for program CAPTURE. Utah State Univ. Press, Logan. $40 \mathrm{pp}$.

Accepted, May 23, 1984 
James D. NICHOLS, Kenneth H. POLLOCK i James E. HINES

\author{
UZYCIE ELASTYCZNEGO MODELU W BADANIACH POPULACJI \\ MAEYCH SSAKOW METODA POWTORNYCH ZEOWIEN: \\ PRZYKEAD TERENOWY NA MICROTUS PENNSYLVANICUS
}

\begin{abstract}
Streszczenie
Elastyczny wzorzec Pollocka (1982) wykorzystano do oceny parametrów populacji $M$. pennsylvanicus z Maryland (Tabele 1, 2). Testowanie modelu zamkniętego udowadnia heterogeniczność prawdopodobieństwa złowień. Model $M_{h}$ (Otis et al., 1979) wybrano jako najdokładniejszy dla oceny wielkości populacji (Tabela 3). Test zgodności dla modelu Jolly-Sebera wskazuje na konieczność odrzucania. tego modelu dla tych przykładowych danych. Ocena wielkości posulacji na podstawie modelu $M_{h}$ była bowiem wyższa niż ocena według modelu Jolly-Sebera (Tabela 4). Oba te wyniki są zgodne $\mathrm{z}$ heterogenicznością prawdopodobieństwa złowień. Autorzy użyli oceny wielkości populacji wyliczonej według modelu $M h$, oceny poziomu przeżywania wg Jolly-Sebera i oceny urodzeń i nachodzenia opartej na połączeniu ocen wielkości populacji i poziomu przeżywania (Tabela 5). Przedyskutowano zalety elastycznego modelu Pollocka i polecono go do przyszłych badań populacyjnych nad drobnymi ssakami przy użyciu metody powtórnych. zlowień.
\end{abstract}

\title{
BOOK RECEIVED
}

J. E. Hill \& J. D. Smith, 1984: Bats: a natural history. British Museum (Natural History). Stron nlb $4+243$. London. Cena 15 f.sz.

Z myślą o zoologach, jak i o przyrodnikach - amatorach John E. Hill z British Museum, który od 25 lat zajmuje się badaniem nietoperzy oraz profesor zoologii, James D. Smith z California State University napisali książkę poświęconą jednemu $\mathrm{z}$ najbardziej zagadkowych rzędów ssakbow.

Już pobieżna lustracja ujawnia, że monografia ta jest prawdziwą kopalnią wiadomości o rękoskrzydłych, tym cenniejszą, że opartą o najnowsze badania. $\mathrm{Na}$ treść jej złożyło się 11 rozdziałów, z których 10 prezentuje współczesny stan wiedzy przyrodniczej o tych zwierzętach, zaś w jednym przedstawiono stosunek człowieka do nietoperzy $w$ różnych krajach, związane z tym mity, legendy i podania, a ponadto korzyści, jak i niedogodności wspólnej egzystencji. 